\title{
Effects of long-term maternal exposure to low doses of PCB126 and PCB153 on the reproductive system and related hormones of young male goats
}

\author{
Irma C Oskam ${ }^{1}$, Jan L Lyche ${ }^{1}$, Anette Krogenæs ${ }^{1}$, Ragnar Thomassen ${ }^{1}$, Janneche U Skaare ${ }^{1,2}$, \\ Richard Wiger $^{3}$, Ellen Dahl ${ }^{1}$, Torres Sweeney ${ }^{4}$, Ádun Stien $^{5}$ and Erik Ropstad ${ }^{1}$ \\ ${ }^{1}$ Department of Production Animal Clinical Science, The Norwegian School of Veterinary Science, Oslo, Norway, \\ ${ }^{2}$ National Veterinary Institute, Oslo, Norway, ${ }^{3}$ Division of Chemical Toxicology, Norwegian Institute of Public \\ Health, Oslo, Norway, ${ }^{4}$ Faculty of Veterinary Medicine and Conway Institute of Biomedical and Biochemical \\ Research, University College, Belfield, Dublin, Ireland and ${ }^{5}$ Department of Biology, University of Tromsø, Norway
}

Correspondence should be addressed to Irma C Oskam, PO Box 8146 Dep., NO-0033 Oslo, Norway;

Email:irma.oskam@veths.no

\begin{abstract}
In this study, female goats were orally exposed to PCB126 or PCB153, at $49 \mathrm{ng} / \mathrm{kg}$ body weight per day and $98 \mu \mathrm{g} / \mathrm{kg}$ body weight per day respectively, from gestational day 60 until delivery at approximately day 150 . Exposure of the offspring continued via lactation until postnatal day 40. Reproductive toxicity in the male offspring was studied by the evaluation of conventional reproductive endpoints as well as flow cytometric analyses of spermatogenesis and sperm chromatin structure.

PCB153-treated animals showed a significant smaller testis diameter in comparison to the control group. Neither of the treated groups showed differences for plasma FSH in comparison to controls. PCB153-treated animals differed significantly from the control group with respect to plasma LH and testosterone levels, whereas PCB126-treated animals only differed from the controls in plasma testosterone concentrations. Neither the PCB126 nor the PCB153 group differed from the controls with respect to the conventional sperm parameters or testis histology. A significant lower ratio of interstitium area to seminiferous tubules area and proportion of diploid testis cells were observed for the PCB153 group. Sperm from PCB153-treated animals showed a significantly higher percentage of sperm with damaged DNA. From the results of the present study it was concluded that PCB153 was able to induce alterations in reproductive endpoints related to the hypothalamic-pituitary-axis as well as to the testis. The effects observed in male kids after a long-term maternal exposure to PCB153 support the concept that exposure to endocrine-disrupting compounds during foetal development may lead to adverse reproductive effects in adult life.

Reproduction (2005) $130731-742$
\end{abstract}

\section{Introduction}

Polychlorinated biphenyls (PCBs) are a group of commercially produced organic chlorines that have been identified as highly lipophilic, persistent environmental pollutants in a variety of biota across the world. Although restrictions were imposed with regard to their production, destruction and storage more than three decades ago, $\mathrm{PCBs}$ remain in the environment and until now only a small number of temporal trend studies have been able to show declining concentrations in a few food chains (Muir et al. 1999). A variety of wildlife and human health concerns are related to PCB-mediated adverse effects and particularly effects associated with their actions as endocrine-disrupting compounds (EDCs) are considered to be potentially hazardous for the reproductive health of both animals and humans (Vos et al. 2000, Damstra et al. 2004, Sharpe \& Irvine 2004).

There are a number of field studies indicating possible adverse reproductive effects from exposure to organic chlorines, particularly PCBs. In a study of the river otter (Lutra canadensis) on the Columbia River in the northwest USA, reduced baculum length and weight, as well as the absence of spermatogenesis, is reported in 8-10 monthold individuals (Henny et al. 1996). In the male population of Florida panthers (Felix concolor coryi) sperm abnormalities, including low ejaculate volume and sperm concentration, poor sperm motility and a high proportion of abnormal sperm, as well as an increase in cryptorchidism, have been reported (Facemire et al. 1995). A decrease in plasma testosterone levels has been reported for juvenile alligators (Alligator mississipienisis) in Lake Apopka, 
Florida, as well as in polar bears (Ursus maritimus) from the Svalbard area in the Norwegian Arctic (Guillette et al. 1996, Oskam et al. 2003). It is not easy to compare and integrate results from wildlife studies since data that report possible relationships between PCB exposure and adverse reproductive effects are often based upon a diversity of species, different exposure conditions, and differences in exposure levels and timing and duration of the exposure.

Experimental animal studies are conducted under more controlled conditions, but are often characterized by their use of relatively high exposures for relatively short observation periods. A large number of in vivo studies in rodents reported perturbed reproductive function in male offspring following PCB exposure during the gestational and lactational periods (Hany et al. 1999, Kim et al. 2001, Fielden et al. 2002). In rodents this period usually lasts for not more than 30 days and a number of the reproductive endpoints used in rodent models have therefore appeared to be of doubtful relevance to humans.

In humans, concerns about perturbed reproductive function related to organic chlorines, including PCBs, are mainly based on apparent increases in a number of disorders observed in the male reproductive system. These include abnormalities in the developing reproductive tract, testicular cancer and reduced plasma testosterone levels, as well as a general reduction in sperm count and quality (Carlsen et al. 1993, Toppari et al. 1996, Sharpe \& Skakkebaek 2003, Toppari 2003). The only supportive evidence relating disturbed reproductive function in humans exposed to PCBs is provided by studies of accidental high exposure levels of PCBs (Guo et al. 2000). There are limited human data associating possible cause-and-effect relationships between chronic low exposure levels of PCBs and adverse reproductive effects, but this is of great concern, since it involves the reproductive health of the population at large. A lack of data concerning PCB exposure during critical stages of development may be of even more concern since reported increases of certain reproductive disorders in adult life are probably the results of in utero exposure during specific life stages (Brouwer et al. 1995, Meerts et al. 2002). In order to detect and interpret possible PCB-associated adverse reproductive effects in men, appropriate experimental animal models are needed and exposure during critical stages of foetal development must be addressed.

In the present study, two single congeners, PCB126 $\left(3,3^{\prime}, 4,4^{\prime}, 5\right.$-pentachlorobiphenyl) and PCB153 (2, $2^{\prime}, 4,4^{\prime}, 5,5^{\prime}$ hexachlorobiphenyl), were studied, each representing the main classes of non-ortho-substituted coplanar and di-orthosubstituted groups of PCBs, respectively (Battershill 1994, Safe 1994). PCB126 is one of the most toxic PCB congeners but is present at fairly low concentrations in the environment of wildlife and humans, which is in sharp contrast to the high concentrations of PCB153 (Bernhoft et al. 1997, van den Berg et al. 1998, Skaare 2001, Fangstrom et al. 2002, Gladen et al. 2003a, Kunisue et al. 2004). Similar to 2,3,7,8tetrachloridibenzo-p-dioxin (TCDD), the toxicity of PCB126 is mediated through binding to the cytosolic aryl hydrocarbon (Ah) receptor. Although it has been recognized that the toxicity exerted by PCB153 is not related to the Ah receptor, information with regard to other possible toxic mechanisms is limited; however, estrogenic activity may be involved (Brouwer et al. 1999, Safe 2001, Korach et al. 2003).

The reproductive biology of small ruminants and humans reveals close similarities and in particular the maternal exposure model of sheep is used to study possible adverse reproductive effects on gonadal development from foetal into adult life (Rhind et al. 2001, Foster et al. 2002). We hypothesized that the exposure to relatively low doses of PCBs could have long-term consequences on the reproductive health of adult male goats. In the present study, goats (Capra hircus) were used as a model and the PCB exposure of the does took place from day 60 of gestation $(G D=60)$ until parturition $(G D=150)$. Thereafter, exposure of the newborn continued by the transfer of the body-fat-stored contaminants via lactation until weaning of the kids at 6 weeks of age (Lyche et al. 2004b).

The present study was conducted after long-term maternal exposure in order to provide new insight concerning possible toxic effects of PCB126 and PCB153 on reproductive and general endocrine function in young adult male goats. Conventional reproductive endpoints were studied and flow-cytometric (FCM) analyses of spermatogenesis and sperm chromatin structure were carried out.

\section{Materials and Methods}

\section{Chemicals}

PCB126 and PCB153 in powder form, with a purity of 99\%, were purchased from Promochem (Ulricehamn, Sweden). To prepare doses, the PCB congeners were dissolved in cyclohexane (Sigma Chemical Co., St Louis, MO, USA) and most of the solvent was evaporated using $\mathrm{N}_{2}$. Corn oil was added and the mixtures sonicated for 5 min. The resulting PCB concentrations were confirmed by high-resolution gas chromatography and the solutions were stored at room temperature to retain their homogeneity.

\section{Animals and treatments}

The present study was conducted on 45 female goats of the Norwegian breed. Estrous cycles were synchronized using a vaginal release device (EAZI-breed CIDR G; Carter Holt Harvey, Agricultural Division, Hamilton, New Zealand) containing $30 \mathrm{mg}$ progesterone, inserted for 18 days. After withdrawal of the device (luteal phase) the does were mated naturally, and the pregnant goats ( $n=10 /$ group) allocated randomly to one of the following groups: PCB126 at $49 \mathrm{ng} / \mathrm{kg}$ body weight (bw) per day, PCB153 at $98 \mu \mathrm{g} / \mathrm{kg}$ bw per day, or vehicle (corn oil) only, 
by oral gavage three times weekly, from GD $=60$ until parturition. The does were kept under natural photoperiodic conditions, indoors in individual pens. They were fed standard hay as well as commercial concentrates and they had free access to water and mineral blocks. From confirmed pregnancy until kidding, the does were weighed weekly and blood samples were collected by jugular venipuncture three times weekly and assayed for luteinizing hormone (LH), follicle-stimulating hormone (FSH), progesterone and prolactin (Lyche et al. 2004a).

The pregnant does in the PCB126 and PCB153 treatment groups and the control animals gave birth to four, ten and seven healthy male kids, respectively. The kids were born during the last two weeks of April, and does and kids were reared together until weaning 6 weeks postpartum. The lactational exposure of the offspring lasted from the day of birth until the day of weaning. Male kids were housed individually in order to prevent them mounting each other and they were fed similarly to the does (see above). At 2 weeks of age the kids received their vaccinations according to the general management procedure for disease prevention in goats.

\section{Sample collection}

Body weights of the kids were recorded once weekly and testis diameter was recorded every second week from 12 weeks of age until they were killed at approximately 40 weeks. The circumferences of the left and right testes were measured with callipers, and the average testis weight was used in the statistical analyses. To characterize effects of treatment on $\mathrm{LH}, \mathrm{FSH}$ and testosterone, blood samples were collected three times weekly over the same period. The samples were collected from the jugular vein into heparinized tubes using a Vacutainer (Leuven, Belgium). Plasma was separated by centrifugation $(1000 \mathrm{~g}, 15 \mathrm{~min}$, $4^{\circ} \mathrm{C}$ ) and subsequently stored at $-20^{\circ} \mathrm{C}$ until further analysis.

The spring-born kids reached puberty in the autumn of the same year when they were 27 weeks of age. During the breeding season, in the presence of a doe in estrus, semen was collected from each buck once per week for six consecutive weeks using an artificial vagina. Semen volume $(\mathrm{ml})$ was recorded immediately after collection using a graduated vial. Sperm concentrations $\left(\times 10^{6} / \mathrm{ml}\right)$ were measured in a sperm photometer (Leo Diagnostics $A B$, Helsingfors, Sweden) and the total sperm number $\left(\right.$ TSPN; $\times 10^{9}$ ) per ejaculate was calculated. Sperm motility was assessed under a phase-contrast microscope ( $\times 400$ magnification), equipped with a heated stage adjusted to $37^{\circ} \mathrm{C}$. The average outcome of three microscopic field judgements was reported (Paulenz et al. 2004). The percentage of live and dead spermatozoa was determined using the nigrosin-eosin staining technique by counting at least 100 spermatozoa under an oil-immersion objective $(\times 1000)$ in a random field. Sperm morphology was assessed on air dried, hematoxylin-stained smears.
Each smear was assessed using a $\times 100$ non-phase contrast objective under oil immersion and at least 200 spermatozoa were assessed; the same operators performed all examinations. At the end of this semen-collection period, final ejaculates were sampled from each goat and cryopreserved (see below) for future FCM assessment.

At the end of the study period all animals were euthanized with an i.v. injection of sodium pentobarbital (University Hospital Pharmacy, Norway) and necropsies were performed. Testes were removed and weighed, and hereafter a longitudinal deep incision was made into the rete testis and approximately $5 \mathrm{~mm}$-thick blocks of tissue were dissected and immediately placed in $2 \mathrm{ml}$ TNE buffer (0.15 M NaCl, $0.01 \mathrm{M}$ Tris/ $\mathrm{HCl}$ and $1 \mathrm{mM}$ EDTA, $\mathrm{pH}$ 7.4) on crushed ice for FCM analysis (Suter et al. 1997). Of the other testis, similar fractions from the same region were fixed in Bouin's fixative for $24 \mathrm{~h}$ prior to storage in $70 \%$ ethanol. Fixed testes were dehydrated through $70 \%$ ethanol and embedded in paraffin.

The procedures were conducted in accordance with the laws and regulations controlling experiments/procedures in live animals in Norway; the Animal Welfare Act of 20 December 1974, no. 73, chapter VI, sections 20-22, and the Regulations on Animal Experimentation of 15 January 1996. In addition, Norway has signed and ratified the European Convention for the Protection of Vertebrate Animals used for Experimental and other Scientific Purposes of 18 March 1986. The Norwegian legislation conforms in all respects with the basic requirements of this Convention and guidelines prepared in pursuance of it.

\section{Semen cryopreservation}

After semen collection and quality assessment, semen was prepared for cryopreservation in French mini straws and stored in fluid nitrogen (Paulenz et al. 2004).

\section{PCB analysis}

Chemical analyses of PCB153 and PCB126 were performed at the Laboratory of Environmental Toxicology, Norwegian School of Veterinary Science, Oslo, Norway. For details on extraction and clean-up, see Andersen et al. (2001). The laboratory is accredited by Norwegian Accreditation as a testing laboratory for these analyses according to the requirements of NS-EN45001 and ISO/IEC Guide 25.

\section{Hormone analysis}

\section{$\mathrm{FSH}$}

Plasma FSH concentrations were determined using a heterologous assay described by Crowe et al. (1997) using anti-oFSH NIDDK-NIH antibody (AFP-C 5288113). The assay was validated for use with goat plasma by demonstrating parallelism between dilutions of goat plasma samples and the standard curve, and no modifications of 
the standard procedures were needed. The standard used as reference preparation was USDA-oFSH-SIAFP-RP-2 (AFP 4117A) and the sensitivity of the assay was $0.012 \mathrm{ng}$ (oFSH-RP)/tube. Intra- and interassay variation coefficients were less than $10 \%$.

\section{$L H$}

Plasma LH concentrations were measured by a heterologous double-antibody RIA described and validated for goat plasma by Beckers et al. (1978). The interassay coefficients of variation for samples with 0.69, 1.95 and $6.68 \mathrm{ng} / \mathrm{ml} \mathrm{LH}$ were $18.8,9.7$ and $9.0 \%$ respectively. The standard curve ranged from 0.2 to $25 \mathrm{ng} / \mathrm{ml}$. Assay sensitivity was $0.8 \mathrm{ng} / \mathrm{ml}$.

\section{Testosterone}

Plasma levels of total testosterone were determined by a solid-phase RIA kit (Coat-A-Count, Total Testosterone, Diagnostic Products Corporation, Los Angeles, CA USA). The assay was validated for use with goat plasma (as described above): no modifications were needed and the intra- and interassay coefficients of variation were less than $10 \%$. The detection limit of the assay was $0.04 \mathrm{ng} / \mathrm{ml}$.

\section{Histological evaluation of testes}

Two cross-sections ( $6 \mu \mathrm{m}$ thickness) of the testes fixed in Bouin's fixative were stained with hematoxylin and eosin. The seminiferous tubules (STs) of each testis section were examined by light microscopy ( $\times 200$ magnification) and each ST was placed into one of three categories - (1) normal spermatogenesis, (2) loose epithelium and (3) apoptotic cells - which were identified by the intense uniform basophilic nucleus with either chromatin condensation or nuclear shrinkage or with the fragmentation of the nucleus into several uniformly basophilic masses.

\section{Testicle tubule epithelium image analysis}

Monochrome digital images (8 bit) were captured using a Leica DM RXA microscope (Leica Microsystems AG, Wetzlar, Germany) with a Spot RT Slider digital camera (Diagnostic Instruments, St Sterling Heights, MI, USA). Subsequently, testicular tissue was measured with the image-analysis software Image-Pro Plus ver. 4.5 (Media Cybernetics, Silver Spring, MD, USA). In the measurements dialog, the line feature was used to draw a line corresponding to the diameter of the tubule lumen, and another corresponding to the outer diameter of the same tubule. The pair of line lengths was measured for each tubule cross-section, at the point where the minimum diameter was found. Ranges of 53-167 tubuli were measured per animal. Additionally, calculations were made of the relative proportion of testicular tissue consisting of seminiferous tubuli [area of seminiferous tubuli/(area of seminiferous tubuli + area of interstitial tissue)]. Ten images were assessed from each individual.

\section{DNA}

FCM analysis of testis cells

For analysis of testicular cell populations, testis tissue was transferred to a $60 \mathrm{~mm}$ Petri dish containing 1-2 $\mathrm{ml}$ TNE buffer and minced with curved surgical scissors to liberate individual cells. Cell suspensions were transferred into plastic test tubes and the tissue fragments were allowed to settle for $1 \mathrm{~min}$. The supernatant was gravity-filtered though a $55 \mu \mathrm{m}$ nylon filter. The DNA of testicular cells was stained by incubating $(1-2) \times 10^{6}$ cells in TNE medium containing $0.1 \%$ Triton $\mathrm{X}-100$ and $1.0 \mu \mathrm{g}$ Hoechst $33258 / \mathrm{ml}$ for $15 \mathrm{~min}$ (see Bjørge et al. 1995). Blue fluorescence was measured using an Argus 100 flow cytometer (Skatron, Lier, Norway). Quantification of the testicular cell populations - haploid cells (1c), diploid cells (2c), S phase and tetraploid cells (4c) - enabled the evaluation of changes in the dynamics of spermatogenesis. The haploid cell population consists of mature cells, composed of condensed spermatids and the immature round and elongating spermatids of earlier maturation stages. Diploid cells are composed of spermatogonial cells in the $G_{1}$ phase, secondary spermatocytes and testicular somatic cells. The tetraploid cell population mainly consists of primary spermatocytes at different stages of the first meiotic division and some spermatogonia in $\mathrm{G}_{2}$ phase. The $\mathrm{S}$ phase, situated between the diploid and tetraploid cell population, reflects the process of replicative DNA synthesis. For the present study, the percentages of cells in the 1c, 2c and 4c populations were estimated from DNA cytograms using the Multicycle Program (Phoenix Flow Systems, San Diego, CA, USA).

\section{Sperm chromatin structure assay (SCSA) of semen samples}

The SCSA defines abnormal chromatin structure as increased susceptibility of sperm DNA to acid-induced denaturation in situ in which the unique metachromatic properties of Acridine Orange are used. A preliminary study showed that the method described by Evenson \& Jost (2000) could be used without modifications. Briefly, semen straws, stored in liquid nitrogen, were thawed in a $37^{\circ} \mathrm{C}$ water bath for $30 \mathrm{~s}$. Hereafter, the semen was diluted in TNE buffer to yield approximately $2 \times 10^{6} \mathrm{sperm} / \mathrm{ml}$, and $0.2 \mathrm{ml}$ of this suspension was mixed with $0.4 \mathrm{ml}$ aciddenaturation solution. After $30 \mathrm{~s}, 1.2 \mathrm{ml}$ of staining solution, containing $6.0 \mu \mathrm{g} / \mathrm{ml}$ Acridine Orange, was added. The samples were analyzed by a Coulter EPICS XL flow cytometer (Beckman Coulter, Luton, Beds, England) equipped with a $15 \mathrm{~mW}$ argon laser with excitation at $488 \mathrm{~nm}$. Both light-scatter and fluorescence data were collected in linear mode. Green fluorescence was detected using a 505-545 nm bandpass filter (FL1) whereas red 
fluorescence was detected using a 660-900 nm bandpass filter (FL4). Measurements were recorded 3 min after staining, the flow rate was adjusted to 100-200 cells and 10000 cells characterized by positive DNA were acquired. A cytogram of green versus red DNA fluorescence was used to identify sperm with denaturated DNA. A gate was set around the sperm with increased red DNA fluorescence (denatured DNA) compared with the main population to determine the percentages of sperm with single-stranded DNA. This percentage was calculated as a percentage of the toal sperm population and was reported as the DNA fragmentation index (DFI) (Fig. 1).

\section{Statistical analysis}

For data on body weight, testis diameter and testosterone, $\mathrm{LH}$ and FSH concentrations, log-transformed data gave a satisfactory fit to the normal distribution and were therefore used in the analyses. The repeated-measurement data structure available on these variables and on semen characteristics were taken into account in the analysis using linear mixed models, in which the categorical variables week of sampling and treatment group were treated as fixed effects, between-kid variation was treated as a random effect and a negative exponential temporal autocorrelation was assumed between observations performed on the same individual. Data on testicular morphology (tubuli diameters, relative proportion of tubuli area) were analyzed with linear mixed models with the categorical variable treatment group as the fixed effect, and a random effect for between-kid variation to take into account the repeated measurements obtained from each animal. The models were fitted using Proc mixed in SAS (Littell et al. 1996). Data on FCM analyses were analyzed utilizing one-way analysis of variance (ANOVA; SAS Institute 2003).

\section{Results}

\section{PCB tissue concentrations}

The concentrations of PCB153, measured in abdominal adipose tissue from PCB153-treated animals at 40 weeks of age, ranged from 2900 to $12700 \mathrm{ng} / \mathrm{g}$ lipid weight (l.w.) (mean, $5800 \mathrm{ng} / \mathrm{g} \mathrm{l.w.).} \mathrm{The} \mathrm{mean} \mathrm{plasma} \mathrm{concentration} \mathrm{of}$ PCB153 in the PCB153 treatment group was $12.9 \mathrm{ng} / \mathrm{g}$ wet weight (w.w.) at birth and $45.6 \mathrm{ng} / \mathrm{g} \mathrm{w.w.} \mathrm{at} 4$ weeks of age. Adipose tissue levels of PCB126 in the PCB126exposed group at 40 weeks of age ranged from 0.28 to $0.80 \mathrm{ng} / \mathrm{g}$ I.w. (mean, $0.49 \mathrm{ng} / \mathrm{g}$ I.w.). The mean plasma levels of PCB126 were below the detection limit at birth and $11 \mathrm{pg} / \mathrm{g}$ w.w. at 4 weeks of age. In unexposed kid adipose tissue the mean concentration of PCB153 was $18 \mathrm{ng} / \mathrm{g}$ I.w. whereas the concentration of PCB126 was below the detection limit. In the goats' milk, the mean fat fraction was $4.2 \%$. The mean concentration of PCB153 was 11805 ng/g l.w. (507 ng/g w.w.). The mean concentration of PCB126 in milk was $5.72 \mathrm{ng} / \mathrm{g}$ l.w. (0.24 ng/g w.w.).

\section{Body weight and testicular diameter}

Exposure to PCB126 and PCB153 did not influence the general health of either does or kids and no signs of overt toxicity were observed. No significant difference was observed in the number of female and male kids born from the exposed does in comparison to the control group. In the present study, the onset of puberty was defined as the moment the highest (mean) plasma testosterone concentration was reached (around week 39 in Fig. 4; see below). The control group reached puberty at 24-27 weeks old; the PCB126 and PCB153 groups reached puberty at 23-26 and 23-27 weeks, respectively.

All male kids were born within an interval of 2 weeks and their overall mean birth weight was $2.9 \mathrm{~kg}$ (S.E., $0.1 \mathrm{~kg}$ ). Throughout the study period, animals from all three treatment groups showed a continuous increase in body weight (Fig. 2a). At the end of the study the overall mean body weight was $30 \mathrm{~kg}$ (S.E., $0.8 \mathrm{~kg}$ ). From birth the PCB126 group was on average heavier than the control group with no significant change over time in the relative difference from the control group (Table 1, Fig. 2a). However, the trend was towards a more pronounced difference in the early phase of the experiment and body weights approached control-group levels after puberty (week 40 onwards) towards the end of the experiment (Fig. 2a). No
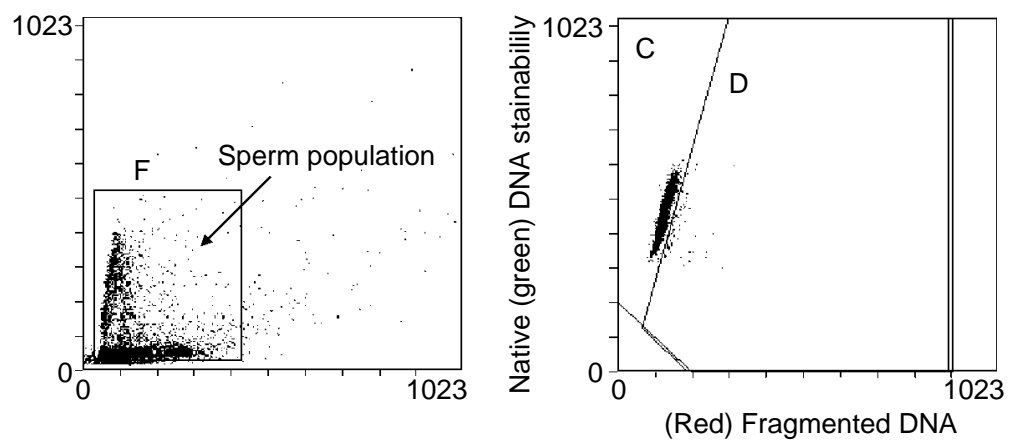

Figure 1 SCSA cytogram of a control animal. A gate is set around the total sperm events (F). The right-hand cytogram presents the fragmented DNA as increased red DNA fluorescence (D) compared with the main population with green DNA fluorescence (C). Data were collected in linear mode. 

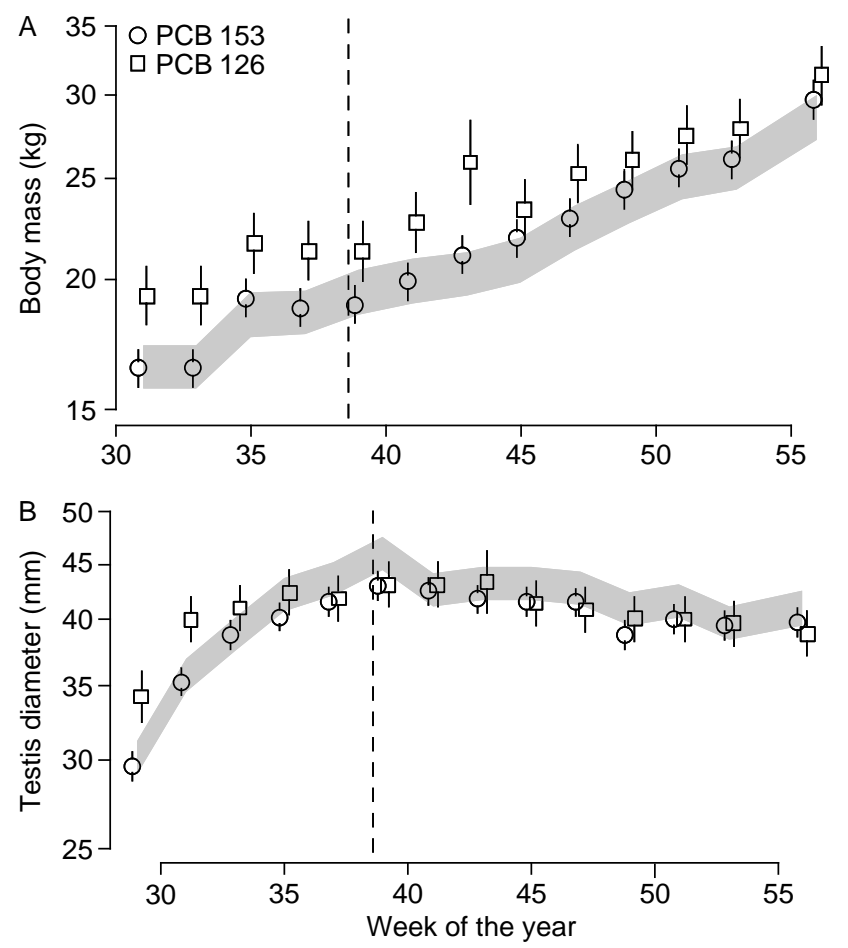

Figure 2 (a) Average body mass ( $\mathrm{kg} ; \pm 1$ S.E.) of the control group and the two PCB-exposure groups for weeks 30-56 after 1 January 2000 (weeks 53-56 indicate the weeks in January 2001). The shaded area shows the S.E. range for the control animals without the mean data points. The time range covered corresponds to kids' ages of 16-40 weeks and the vertical dashed line marks puberty. The $y$ axis is on a logarithmic scale. (b) Average testis diameter (mm; \pm 1 S.E.) of control animals and the two PCB-exposure groups for weeks 30-56 after 1 January 2000. Details are as for panel (a).

significant weight difference was observed between the PCB153 and control groups (Table 2, Fig. 2a).

The average testis diameter increased in all groups prior to puberty (Fig. 2b); however, the PCB126 group tended to have larger testes at the first two time points and lower increases in diameter thereafter, resulting in very similar testis diameters in the two PCB-treated groups around and after puberty. After the onset of puberty, the testes stopped growing and rather tended to decline towards the end of the experiment (Fig. 2b). A significant effect of treatment was found for the PCB153 group (Table 2). This was associated with a general pattern of a smaller testis diameter in the PCB153 group compared with the control group from around puberty onwards. No significant treatment effect was observed for PCB126 (Table 1).

\section{Hormone analyses: $\mathrm{FSH}, \mathrm{LH}$, and testosterone}

Overall mean plasma FSH concentrations showed maximum levels at the beginning of the sample collection, and decreased to low levels around puberty (Fig. 3). The plasma FSH concentration was not significantly affected by PCB153 treatment (Table 2). For the analysis of the PCB126-treated group, the sample included only two animals, which makes it difficult to make a plausible conclusion (Table 1). From 12-14 weeks of age until week 30 the concentrations of $\mathrm{LH}$ were high, followed by a period with very variable levels (weeks 30-37, ages 14-24), reaching a peak just before puberty and a decrease thereafter (Fig. 4a). Both of the PCB-treated groups showed very similar patterns in $\mathrm{LH}$ concentrations even though only the PCB153-treated group differed significantly from the control group (Fig. 4a, Tables 1 and 2). The PCBtreated groups differed from the control (Table 2, Fig. 4a) by having a strong decline in the mean plasma $\mathrm{LH}$ concentrations around week 33 (Fig. 4a). Also, after puberty the mean plasma LH concentrations dropped off more quickly to low basal concentrations in the PCB-treated groups than in the control group (Fig. 4a).

From the beginning of the sampling period (animals approximately 12 weeks of age), the control group as well as the two exposure groups showed a similar trend for the mean plasma testosterone concentration (Fig. 4b). At first increases in the mean plasma testosterone concentration gave peak concentrations approximately 7 weeks before the onset of puberty. Thereafter, mean plasma testosterone concentrations decreased before increasing again to a second peak that defined puberty (Fig. 4b). Over a period of approximately 10 weeks following puberty, all three groups showed a relatively high mean plasma testosterone concentration, corresponding to the breeding season, and thereafter a drop to low levels towards the end of the study period. Even though the general patterns in mean plasma testosterone concentrations were similar in all three groups, both the PCB126- (Table 1) and PCB153-treated (Table 2) animals differed significantly from the controls. Before the onset of puberty, both exposure groups showed higher mean plasma testosterone concentrations than the

Table 1 Summary of $F$ tests and associated $P$ values for the effect of the categorical predictor variables week of sampling, treatment group and the week-treatment interaction, on response variables measured repeatedly over time on control $(n=7)$ and PCB126-treated kids $(n=4)$.

\begin{tabular}{llll}
\hline Response & Week & Treatment & Week $\times$ treatment \\
\hline Log body weight & $F_{12,106}=13.33, P<0.0001$ & $\boldsymbol{F}_{\mathbf{1 , 9}}=\mathbf{2 7 . 2 7 ,} \boldsymbol{P}=\mathbf{0 . 0 0 0 5}$ & $F_{12,106}=0.21, P=1.00$ \\
Log testis diameter & $F_{13,114}=7.17, P<0.0001$ & $F_{1,9}=0.00, P=0.96$ & $F_{13,114}=1.08, P=0.39$ \\
Log LH & $F_{26,323}=5.54, P<0.0001$ & $F_{1,9}=0.96, P=0.35$ & $F_{26,232}=0.95, P=0.54$ \\
Log FSH & $F_{15,102}=5.41, P<0.0001$ & $F_{1,7}=1.57, P=0.25$ & $F_{15,102}=1.20, P=0.29$ \\
Log testosterone & $F_{27,332}=9.68, P<0.0001$ & $F_{1,9}=0.01, P=0.93$ & $\boldsymbol{F}_{\mathbf{2 6 , 3 2 3}}=\mathbf{1 . 6 4}, \boldsymbol{P}=\mathbf{0 . 0 3}$ \\
\hline
\end{tabular}

For FSH analysis, $n=2$. Significant treatment and week-treatment interaction effects are given in bold. 
Table 2 Summary of $F$ tests and associated $P$ values for the effect of the categorical predictor variables week of sampling, treatment group and the week-treatment interaction, on response variables measured repeatedly over time on control $(n=7)$ and PCB153-treated kids $(n=10)$.

\begin{tabular}{llll}
\hline Response & \multicolumn{1}{c}{ Week } & \multicolumn{1}{c}{ Treatment } & Week $\times$ treatment \\
\hline Log body weight & $F_{12,179}=28.84, P<0.0001$ & $F_{1,15}=0.93, P=0.35$ & $F_{12,179}=0.12, P=1.00$ \\
Log testis diameter & $F_{13,194}=18.73, P<0.0001$ & $\boldsymbol{F}_{1,15}=\mathbf{5 . 9 0}, \boldsymbol{P}=\mathbf{0 . 0 3}$ & $F_{13,194}=0.20, P=1.00$ \\
Log LH & $F_{26,379}=6.69, P<0.0001$ & $\boldsymbol{F}_{1,15}=\mathbf{1 4 . 4 3}, \boldsymbol{P}=\mathbf{0 . 0 0 2}$ & $\boldsymbol{F}_{\mathbf{2 6 , 3 7 9}}=\mathbf{1 . 7 1}, \boldsymbol{P}=\mathbf{0 . 0 1 7}$ \\
Log FSH & $F_{16,156}=6.16, P<0.0001$ & $F_{1,11}=0.16, P=0.69$ & $F_{15,156}=1.33, P=0.19$ \\
Log testosterone & $F_{27,388}=16.67, P<0.0001$ & $F_{1,15}=0.00, P=0.99$ & $\boldsymbol{F}_{27, \mathbf{3 8 8}}=\mathbf{1 . 8 5}, \boldsymbol{P}=\mathbf{0 . 0 0 7}$
\end{tabular}

Significant treatment and week-treatment interaction effects are given in bold.

control group whereas concentrations were lower from around puberty and for about 5 weeks of the subsequent breeding period (Fig. 4b).

\section{Evaluation of semen parameters and histological evaluation of the testes}

Neither the PCB126 nor the PCB153 group differed from the controls in average semen volume (overall mean, $0.65 \mathrm{ml}$; S.E., $0.05 \mathrm{ml}$ ), sperm concentration (overall mean, $152 \times 10^{6}$ cells $/ \mathrm{ml}$; S.E., $\left.5.9 \times 10^{6} \mathrm{cell} / \mathrm{s} / \mathrm{ml}\right)$, total sperm number (overall mean, $97 \times 10^{9}$; S.E., $6.7 \times 10^{9}$ ), sperm motility (overall mean, $67 \%$; S.E., $2.5 \%$ ) or percentage of live/dead sperm (overall mean, $97 \%$; S.E., $0.002 \%$ ). Also, the sperm morphology of PCB-exposed groups did not differ significantly from the controls in sperm morphology.

In all three treatment groups cells at all stages of spermatogenesis were present and more than $90 \%$ of the STs revealed normal spermatogenesis. Furthermore, apoptotic germ cells were present within the STs but this was less than $10 \%$ for all groups. The presence of loose epithelium in the STs was rare and mostly due to the histological preparation. None of the groups showed signs of apoptosis in the interstitial Leydig cells.

\section{Testicle tubule epithelium image analysis}

The morphometrical quantification of the STs showed no significant difference between the control group and the

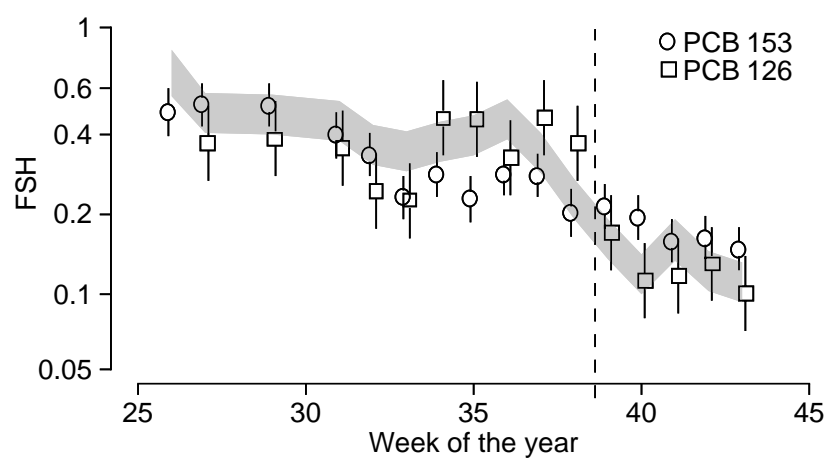

Figure 3 Average plasma FSH concentrations ( $\mathrm{ng} / \mathrm{ml} ; \pm 1$ S.E.) in the kids in the control group and two PCB-exposure groups for weeks 26-43 after 1 January 2000. The shaded area shows the S.E. range for the control animals without the mean data points. The time range covered corresponds to kids' ages of 12-43 weeks and the vertical dashed line marks puberty. The $y$ axis is on a logarithmic scale.
PCB-treated groups when the inner or outer diameters of the STs were considered. However, a significant lower ratio of interstitium area to ST area was observed for the PCB153 group when compared with the control group (Table 3).

\section{SCSA of semen samples}

For all three groups, DNA FCM made it possible to distinguish haploid, diploid and tetraploid testicular cell populations. The PCB126-treated group of kids had a significantly higher proportion of haploid cell and lower
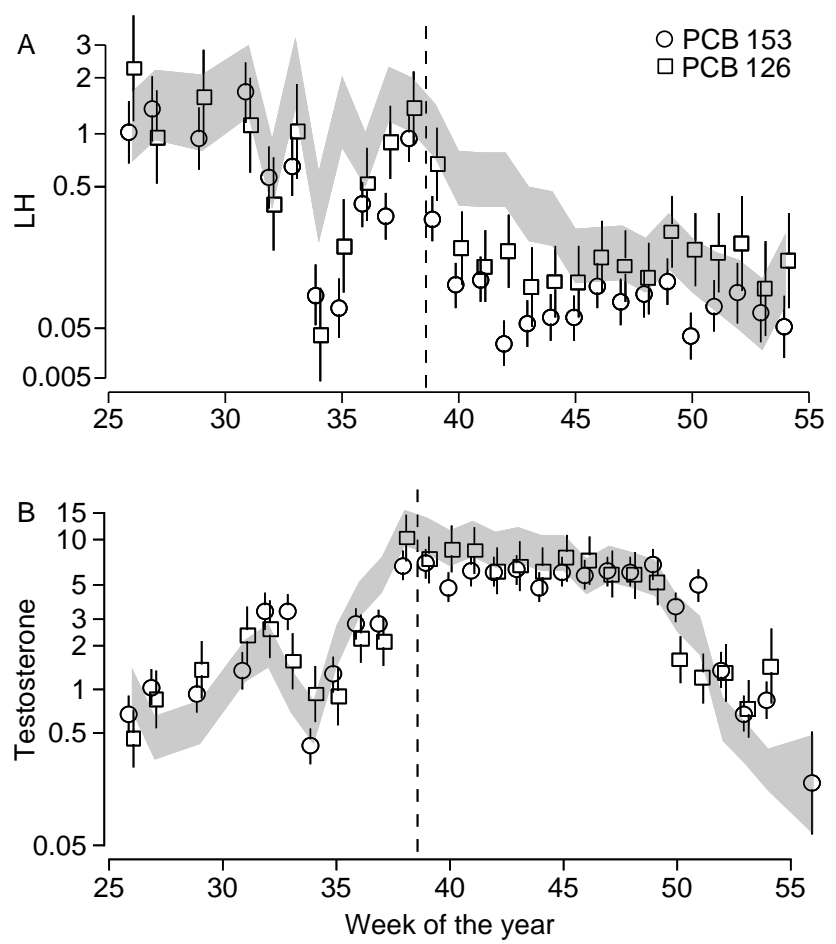

Figure 4 (a) Average plasma LH concentrations ( $\mathrm{ng} / \mathrm{ml}$; \pm 1 S.E.) of control animals and the two PCB-exposure groups for weeks 26-54 after 1 January 2000 (weeks 53-54 indicate the weeks in January 2001). The shaded area shows the S.E. range for the control animals without the mean data points. The time range covered corresponds to kids' ages of 12-38 weeks and the vertical dashed line marks puberty. The $y$ axis is on a logarithmic scale. (b) Average plasma testosterone concentrations ( $\mathrm{ng} / \mathrm{ml} ; \pm 1$ S.E.) of control animals and the two PCB-exposure groups for week 26 to 56 after 1 January 2000 (weeks $53-56$ indicate the weeks in January 2001). The time range corresponds to $12-40$ weeks. Details are as for panel (a). 
Table 3 FCM analysis of testicular cell populations, SCSA and image analysis of testis tissue on control kids $(n=7)$, PCB126-treated kids $(n=4)$ and PCB153-treated kids $(n=10)$.

\begin{tabular}{|c|c|c|c|c|c|}
\hline & \multicolumn{3}{|c|}{ Testicular cell populations (\%) } & \multirow[b]{2}{*}{ SCSA (\% DFI) } & \multirow{2}{*}{$\begin{array}{l}\text { Image analysis } \\
\text { Ratio of interstitium/ST }\end{array}$} \\
\hline & Haploid cells & Diploid cells & Tetraploid cells & & \\
\hline Control & $69.5(0.9)$ & $13.9(0.4)$ & $12.3(0.5)$ & $2.9(0.5)$ & $0.68(0.01)$ \\
\hline PCB126 & 73.4 (1.6) & $11.6(0.2)$ & $11.5(1.4)$ & $3.4(0.3)$ & $0.65(0.02)$ \\
\hline PCB153 & $70.4(1.0)$ & $12.5(0.5)$ & $12.3(0.7)$ & $6.5(1.2)$ & $0.61(0.001)$ \\
\hline
\end{tabular}

Mean DFI (\%) expresses the percentage of sperm with fragmented DNA. Image analysis shows the ratio of intersitium/seminiferous tubuli (ST).

In all cases means \pm S.E. are shown. Significant differences in comparison with the control group are shown in bold.

proportion of diploid cells than the control (Table 3). The PCB153-treated group differed from the controls by having a lower proportion of diploid cells (Table 3).

There was no significant difference in the fraction of sperm with fragmented DNA (DFI) between the PCB126 and control groups. However, the PCB153 group had a significantly higher DFI than the control animals (Table 3 ).

\section{Discussion}

In the present study it was hypothesized that exposure to relatively low doses of PCB126 and PCB153 might induce alterations in the reproductive system of male offspring exposed during gestation and lactation. A number of studies in mammals have documented the transfer of PCBs through the placenta to the fetus, and via milk to the neonate (Jacobson \& Jacobson 1997, Faroon et al. 2000, Chen et al. 2001, Ayotte et al. 2003). In this study, approximately $9 \%$ of PCB153 and $6 \%$ of PCB126 was transferred from the mothers to their kids during gestation and lactation (Lyche et al. 2004b). However, the postnatal intake of PCB153 via milk contributed to a much higher fraction of the body burden following birth than the prenatal exposure since almost $100 \%$ of PCB153 was transferred from the does to the offspring via milk. The mean adipose tissue concentration of PCB126 and PCB153 in 40-week-old kids were respectively 0.49 and $5800 \mathrm{ng} / \mathrm{g}$ I.w., concentrations that were comparable to or considerably lower than levels measured in a range of wildlife and human studies (Dewailly et al. 1993, Guillette et al. 1999, Den Hond et al. 2002, Gladen et al. 2003b, Glynn et al. 2003).

In the present study a significant higher body weight was observed for the PCB126-treated animals compared with the control group. Prenatal PCB exposure is usually associated with decreases in parameters such as body and liver weight and weight of the gonads and/or accessory sex organs (Cook \& Meisami 1991, Desaulniers et al. 1997, Porterfield \& Hendry 1998, Hany et al. 1999). A biological explanation for the observed higher body weight in the PCB126-exposed animals remains unclear especially since no advanced onset of puberty was observed. Male goats reach puberty when body weight is about $40 \%$ that of the adult weight. Comparable with previous studies, the onset of puberty in this study is characterized by high mean $\mathrm{LH}$ concentrations at about $12-14$ weeks of age that is suggested to induce testicular growth and spermatogenesis in pubescent goat kids. The relatively high concentrations of $\mathrm{FSH}$ are reported to enhance the production of steroid biosynthetic enzymes and increase the formation of LH receptors in the testis followed by increased production of testosterone (Foster 1994, Hall 1994, Ahmad et al. 1996, Brooks et al. 1996, Foster et al. 2002, Abdennebi et al. 2003). In conformity with the female kids in our parallel study (Lyche et al. 2004a), the PCB153-exposed male kids showed a significant effect of treatment on the mean plasma LH concentration. However, the observed changes in the $\mathrm{LH}$ profile were not attended with any alteration in the mean plasma FSH concentration and no advanced onset of puberty was observed. This in contrast with the female kids.

In small ruminants, the placental transfer of EDCs during the prenatal period GD 60-150 ensures the exposure of testes and hypothalamic-pituitary-testicular axis during critical stages of male fetal development (Brooks et al. 1996, Sweeney et al. 2000). Little is known about the regulation and crosstalk between $\mathrm{LH}$ and $\mathrm{FSH}$ and significant differences between species are demonstrated (Jansen et al. 1993, Gerhard et al. 1998, Abdennebi et al. 1999). Most evidence of the disruption of $\mathrm{LH}$ secretion by PCBs is derived from laboratory animal studies; for example, daily exposure of lactating rats to Aroclor 1242, reduced plasma testosterone and LH levels as well as a reduction in the number of Leydig cells in the testis. Furthermore, in a study with adult male rats it was suggested that PCB126 affected both the hypothalamicpituitary-axis and the testes (Desaulniers et al. 1999). At doses of 25 and $100 \mu \mathrm{g} / \mathrm{kg}$ per day, plasma LH and thyroxine concentrations were decreased whereas the plasma FSH concentrations were reduced at the highest dose of $400 \mu \mathrm{g} / \mathrm{kg}$ per day. In the same study, two other treatment groups received estradiol-17 $\beta$ or PCB153. These two treatment groups differed with the controls by significant higher plasma thyroxine levels and for both groups the plasma $\mathrm{FSH}$ and $\mathrm{LH}$ concentrations were significantly lower in comparison with the control group. From this study it was concluded that PCB153 possesses estrogenic properties based on the similarity between the effect of estradiol and PCB153 on plasma thyroxine and FSH (Desaulniers et al. 1999). 
Evans et al. (2004) studied the effects of long-term exposure to bisphenol A (BPA), octylphenol and diethylstilbestrol on gonadotropin secretion in prepubertal female sheep (Evans et al. 2004). Diethylstilbestrol was found to reduce both gonadotropins, BPA inhibited LH secretion and treatment with octylphenol was without any effect. The authors suggested that the differential effects of the three different EDCs could, among others, reflect differences in the mechanisms of the compounds tested. As to the ability of BPA to decrease plasma LH concentrations and not affect FSH secretion, several mechanisms of action were suggested, including the impact upon the hypothalamus and gonadotropin-releasing hormone secretion as well as different binding affinities for the estrogen receptor. Similar to the differential effects of BPA in the study of Evans et al. (2004), maternal exposure to PCB153 was also shown in the present study to affect the plasma testosterone and $\mathrm{LH}$ concentrations but not the plasma FSH concentrations.

In the present study, significant lower plasma testosterone concentrations were observed for both PCB153 and PCB126. Our results support the documented effects demonstrated by Wojtowicz et al. (2000). For this in vitro study, PCB126 and PCB153 were selected as model substances based on their different toxicity mechanisms of action. Cultured theca cells were supplemented with PCB126 or PCB153. Both congeners showed a decrease in testosterone secretion due to time-dependent and cellspecific differences in PCB153 and PCB126 action on follicular cells steroidogenesis (Gregoraszczuk et al. 2003). Additionally, Fukazawa et al. (2003) reported the effects of PCB126 on a mouse neonatal testicular organ culture system where it was shown that PCB126 directly affected the expression of steroidogenic enzyme genes (Fukuzawa et al. 2003). Moreover, in an in vivo study where female Wistar rats were treated orally on GD 15 with a single dose of PCB126, reduced plasma testosterone concentrations were found in the male offspring on postnatal day 140. Until now, the mechanism by which PCB153 causes its effect on plasma testosterone is less defined and requires further investigation in both in vitro and in vivo studies.

Revised testing guidelines considering perturbed male reproductive function after maternal or prepubertal exposure include the assessment of conventional sperm parameters and an expanded list of organs for gross pathology, gravimetric analysis and/or histopathology to identify and characterize effects at the target organ (Gray et al. 1997, Cooke et al. 1998, Kavlock 1999, Stoker et al. 2000). Probably, in comparison with rodents, the testosterone levels of goats must be considerably lower to have an effect on spermatogenesis, since in our study the observed lower ratio of interstitium area to ST area and lower testis diameter did not go together with morphological effects on the STs in terms of on changes in the number of germ cells, Sertoli cells or interstitial Leydig cells (Mably et al. 1991). The FCM analysis confirmed the histological findings since only the diploid subpopulation was apparently affected by the exposure to PCB153. Since the diploid population includes spermatogonial cells, secondary spermatocytes and testicular somatic cells, and no compensatory changes in the other testis cell populations were observed, it may be that the decrease in the diploid population is partially related to a decrease in Leydig cells. From this perspective the significant increase in the subpopulation of haploid cells and concomitant decrease in diploid cell population observed after PCB126 exposure is also difficult to explain because, aside from the changes in the plasma testosterone concentration, no other effects were found. However, more detailed quantitative evaluation is warranted for both PCB126 and PCB153.

Spermatogenesis is a complex process in which stem cell spermatogonia, through a series of proliferating and differentiating events, become mature spermatozoa. No changes were detected by conventional sperm analysis and therefore it may be indicated that spermatogenesis in the pubescent buck was not impaired. However, the corroborating SCSA detected a significant increase in the percentage of fragmented DNA after exposure to PCB153. A limited number of studies have investigated the toxicological effects on testicular cells and spermatozoa by using the SCSA assessment. In a number of species, including humans, abnormal sperm chromatin and DNA-strand breaks have been shown to negatively affect fertility (Evenson et al. 1999, 2003, Evenson \& Jost 2000, Januskauskas et al. 2003). Although the percentage of DFI (mean, 6.5\%; S.E., $1.2 \%$ ) for the PCB153-exposed animals was suggested to be relatively low, it was more than doubled in comparison to the control animals (mean, $2.6 \%$; S.E., $0.5 \%$ ). In a recent comprehensive study, it was shown that the SCSA is able to distinguish between fertility levels of animals with proven fertility in the highest ranges (Waterhouse et al. 2005). The best fertilization capacity was seen in a group of bulls with the lowest percentage of $\mathrm{DFI}$, whereas a second group of bulls, with a moderate increase in the percentage of DFI, was significantly less fertile than the best group. In the present study, PCB153-exposed male kids showed a percentage of DFI similar to the second group of less-fertile bulls. However, whether or not fertility in the kids is affected is not known. Nevertheless, an important factor in the abnormal development of the embryo is the degree of DNA damage (Ahmadi \& Ng 1999, Waterhouse et al. 2005). In this perspective the increased percentage of DFI for the PCB153 exposure may be of biological relevance if the low exposure doses in this study, or even higher exposure levels detected elsewhere, are able to induce DNA sperm damage that goes beyond the levels of DNA-repair possibility in the oocyte.

In summary, it has been demonstrated by the present study that goats are an appropriate species to serve as a gestational and lactation exposure model for the exposure to EDCs. In the male kids, the low-dose exposure of PCB126 resulted, on average, in a significantly lower plasma testosterone concentration but no other adverse 
reproductive effects were observed. PCB153 was able to induce reproductive effects related to the hypothalamicpituitary-axis as well as to the testis. Based on the differential effect on the gonadotropins and the treatment-related effects on the plasma testosterone levels, the results of our study do indicate a possible estrogenic effect of PCB153. Determination of the biological relevance of the results from goats to men requires further investigation. The possible perturbation in the process of spermatogenesis was not to be concluded from histopathological evaluation of the testis or from the evaluation of sperm parameters. However, the increased percent of sperm DNA damage, showing altered sperm chromatin structure, is an indication that the long-term maternal exposure to a low dose of PCB153 may induce a possible effect on reproductive health in adult life.

\section{Acknowledgements}

We thank Kjell Andersen Berg, Beate Carolin, Lise Evensen, Lill-Wenche Fredriksen, Signe Haugen, Heiko Paulenz, Anuschka Polder, Øyvind Ropstad, Jens Røhnebæk, Elin Røyset, Unni Sverre, Lise Lotte Torp and Karin Waterhouse for their technical assistance and support. This work was supported by grant 127534/720 from the Norwegian Research Council. The authors declare that there is no conflict of interest that would prejudice the impartiality of this scientific work.

\section{References}

Abdennebi L, Couture L, Grebert D, Pajot E, Salesse R \& Remy JJ 1999 Generating FSH antagonists and agonists through immunization against $\mathrm{FSH}$ receptor $\mathrm{N}$-terminal decapeptides. Journal of Molecular Endocrinology 22 151-159.

Abdennebi L, Chun EY, Jammes H, Wei D \& Remy JJ 2003 Maintenance of sexual immaturity in male mice and bucks by immunization against $\mathrm{N}$-terminal peptides of the follicle-stimulating hormone receptor. Biology of Reproduction 68 323-327.

Ahmad N, Noakes DE \& Wilson CA 1996 Secretory profiles of LH and testosterone in pubescent male goat kids. Small Ruminant Research 21 51-56.

Ahmadi A \& Ng SC 1999 Fertilizing ability of DNA-damaged spermatozoa. Journal of Experimental Zoology 284 696-704.

Andersen M, Lie E, Derocher Andrew E, Belikov SE, Bernhoft A \& Boltunov AN et al. 2001 Geographic variation of PCB congeners in polar bears (Ursus maritimus) from Svalbard east to the Chukchi Sea. Polar Biology 24 231-238.

Ayotte P, Muckle G, Jacobson JL, Jacobson SW \& Dewailly E 2003 Assessment of pre- and postnatal exposure to polychlorinated biphenyls: lessons from the Inuit cohort study. Environmental Health Perspectives 111 1253-1258.

Battershill JM 1994 Review of the safety assessment of polychlorinated-biphenyls (PCBs) with particular reference to reproductive toxicity. Human \& Experimental Toxicology 13 581-597.

Becker JF, Wouters-Ballman P, Ectors F \& Derivaux J 1978 Induction de l'oestrus cheze les genisses en anoestrus fonctionnel. Annales Medicine Veterinaire 122 597-604.

Bernhoft A, Wiig O \& Skaare JU 1997 Organochlorines in polar bears (Ursus maritimus) at Svalbard. Environmental Pollution 95 $159-175$.

Bjørge C, Wiger R, Holme JA, Brunborg G, Andersen R, Dybing E \& Soderlund EJ 1995 In vitro toxicity of 1,2-dibromo-3-chlor- opropane (DBCP) in different testicular cell types from rats. Reproductive Toxicology 9 461-473.

Brooks AN, Hagan DM, Sheng C, McNeilly AS \& Sweeney T 1996 Prenatal gonadotrophins in the sheep. Animal Reproduction Science 42 471-481.

Brouwer A, Ahlborg UG, van den Berg M, Birnbaum LS, Boersma ER \& Bosveld B et al. 1995 Functional aspects of developmental toxicity of polyhalogenated aromatic hydrocarbons in experimental animals and human infants. European Journal of Pharmacology Environmental Toxicology and Pharmacology 293 1-40.

Brouwer A, Longnecker MP, Birnbaum LS, Cogliano J, Kostyniak P \& Moore J et al. 1999 Characterization of potential endocrine-related health effects at low-dose levels of exposure to PCBs. Environmental Health Perspectives 107 639-649.

Carlsen E, Giwercman A \& Skakkebaek NE 1993 Declining sperm counts and increasing incidence of testicular cancer and other gonadal disorders - is there a connection. Irish Medical Journal 86 $85-86$.

Chen CY, Hamm JT, Hass JR \& Birnbaum LS 2001 Disposition of polychlorinated dibenzo-p-dioxins, dibenzofurans, and non-ortho polychlorinated biphenyls in pregnant long evans rats and the transfer to offspring. Toxicology and Applied pharmacology 173 $65-88$.

Cook J \& Meisami E 1991 Early hypothyroidism in rats causes increased adult testis and reproductive organ size but does not change testosterone levels. Endocrinology 129 237-243.

Cooke GM, Price CA \& Oko RJ 1998 Effects of in utero and lactational exposure to 2,3,7,8-tetrachlorodibenzo-p-dioxin (TCDD) on serum androgens and steroidogenic enzyme activities in the male rat reproductive tract. Journal of Steroid Biochemical Molecular Biology 76 347-354.

Crowe MA, Padmanabhan V, Hynes N, Sunderland SJ, Enright WJ, Beitins IZ \& Roche JF 1997 Validation of a sensitive radioimmunoassay to measure serum follicle-stimulating hormone in cattle: correlation with biological activity. Animal Reproduction Science 48 123-136.

Damstra T, Barlow S, BergmanÅ, Kavlock RJ \& van der Paauw CG 2004 Global Assessment of the State-of the Science of Endocrine Disruptors. International Programme on Chemical Safety 2002. International Programme on Chemical Safety. Geneva, Switzerland.

Den Hond E, Roels HA, Hoppenbrouwers K, Nawrot T, Thijs L \& Vandermeulen C et al. 2002 Sexual maturation in relation to polychlorinated aromatic hydrocarbons: Sharpe and Skakkebaek's hypothesis revisited. Environmental Health Perspectives $\mathbf{1 1 0}$ $771-776$.

Desaulniers D, Poon R, Phan W, Leingartner K, Foster WG \& Chu I 1997 Reproductive and thyroid hormone levels in rats following 90-day dietary exposure to PCB 28 (2,4,4'-trichlorobiphenyl) or PCB 77 (3,3'4,4'-tetrachlorobiphenyl). Toxicology and Industrial Health 13 627-638.

Desaulniers D, Leingartner K, Wade M, Fintelman E, Yagminas A \& Foster WG 1999 Effects of acute exposure to PCBs 126 and 153 on anterior pituitary and thyroid hormones and FSH isoforms in adult Sprague Dawley male rats. Toxicological Sciences 47 158-169.

Dewailly E, Bruneau S, Ayotte P, Laliberte C, Gingras S, Belanger D \& Ferron L 1993 Health status at birth of Inuit newborn prenatally exposed to organochlorines. Chemosphere 27 359-366.

Evans NP, North T, Dye S \& Sweeney T 2004 Differential effects of the endocrine-disrupting compounds Bisphenol-A and Octylphenol on gonadotropin secretion, in prepubertal ewe lambs. Domestic Animal Endocrinology 26 61-73.

Evenson DP, Jost LK, Marshall D, Zinaman MJ, Clegg E \& Purvis K et al. 1999 Utility of the sperm chromatin structure assay as a diagnostic and prognostic tool in the human fertility clinic. Human Reproduction 14 1039-1049.

Evenson DP, Larson-Cook KL \& Virro M 2003 Sperm chromatin structure assay (SCSA $\left.{ }^{\circledR}\right)$ parameters relationship with fertilization rate, blastocyst development and pregnancy outcomes following in vitro fertilization (IVF) and IVF with intracytoplasmic sperm injection (ICSI). Fertility and Sterility 80 S113-S114. 
Facemire CF, Gross TS \& Guillette LJ Jr 1995 Reproductive impairment in the Florida panther: nature or nurture? Environmental Health Perspectives 103 suppl 4 79-86.

Fangstrom B, Athanasiadou M, Grandjean P, Weihe P \& Bergman A 2002 Hydroxylated PCB metabolites and PCBs in serum from pregnant Faroese women. Environmental Health Perspectives 110 895-899.

Faroon O, Jones D \& De Rosa C 2000 Effects of polychlorinated biphenyls on the nervous system. Toxicology and Industrial Health $16307-333$

Fielden MR, Halgren RG, Fong CJ, Staub C, Johnson L, Chou K \& Zacharewski TR 2002 Gestational and lactational exposure of male mice to diethylstilbestrol causes long-term effects on the testis, sperm fertilizing ability in vitro, and testicular gene expression. Endocrinology 143 3044-3059.

Foster DL 1994 Puberty in the sheep. In The Physiology of Reproduction, 2nd edn, pp 411-453. Eds E Knobil \& JD Neil. New York: Raven Press.

Foster DL, Padmanabhan V, Wood RI \& Robinson JE 2002 Sexual differentiation of the neuroendocrine control of gonadotrophin secretion: concepts derived from sheep models. Reproduction (Cambridge, England) Supplement 59 83-99.

Fukuzawa NH, Ohsako S, Nagano R, Sakaue M, Baba T, Aoki Y \& Tohyama C 2003 Effects of 3,3',4,4',5-pentachlorobiphenyl, a coplanar polychlorinated biphenyl congener, on cultured neonatal mouse testis. Toxicology In Vitro 17 259-269.

Gerhard I, Daniel V, Link S, Monga B \& Runnebaum B 1998 Chlorinated hydrocarbons in women with repeated miscarriages. Environmental Health Perspectives 106 675-681.

Gladen BC, Doucet J \& Hansen LG 2003a Assessing human polychlorinated biphenyl contamination for epidemiologic studies: Lessons from patterns of congener concentrations in Canadians in 1992. Environmental Health Perspectives 111 437-443.

Gladen BC, Shkiryak-Nyzhnyk ZA, Chyslovska N, Zadorozhnaja TD \& Little RE $2003 b$ Persistent organochlorine compounds and birth weight. Annals of Epidemiology 13 151-157.

Glynn AW, Granath F, Aune M, Atuma S, Darnerud PO \& Bjerselius R et al. 2003 Organochlorines in Swedish women: determinants of serum concentrations. Environmental Health Perspectives 111 349-355.

Gray LE, Kelce WR, Wiese T, Tyl R, Gaido K \& Cook J et al. 1997 Endocrine screening methods workshop report: detection of estrogenic and androgenic hormonal and antihormonal activity for chemicals that act via receptor or steroidogenic enzyme mechanisms. Reproductive Toxicology 11 719-750.

Gregoraszczuk EL, Sowa M, Kajta M, Ptak A \& Wojtowicz A 2003 Effect of PCB 126 and PCB 153 on incidence of apoptosis in cultured theca and granulosa cells collected from small, medium and large preovulatory follicles. Reproductive Toxicology 17 465-471.

Guillette LJ, Brock JW, Rooney AA \& Woodward AR 1999 Serum concentrations of various environmental contaminants and their relationship to sex steroid concentrations and phallus size in juvenile American alligators. Archives of Environmental Contamination and Toxicology 36 447-455.

Guillette LJ, Pickford DB, Rooney AA \& Percival HF 1996 Reduction in penis size and plasma testosterone concentrations in juvenile alligators living in a contaminated environment. General Comparative Endocrinology 101 32-42.

Guo YL, Hsu PC, Hsu CC \& Lambert GH 2000 Semen quality after prenatal exposure to polychlorinated biphenyls and dibenzofurans. Lancet 356 1240-1241.

Hall PF 1994 Testicular steroid synthesis: organization and regulation. In The Physiology of Reproduction, edn 2, pp 1335-1363. Eds E Knobil \& JD Neil. New York: Raven Press.

Hany J, Lilienthal H, Sarasin A, Roth-Harer A, Fastabend A \& Dunemann L et al. 1999 Developmental exposure of rats to a reconstituted PCB mixture or aroclor 1254: effects on organ weights, aromatase activity, sex hormone levels, and sweet preference behavior. Toxicology and Applied Pharmacology 158 231-243.
Henny CJ, Grove JA., Hedstrom OR 1996 A Field Evaluation of Mink and Otter on the Lower Columbia River and the Influence of Enviromental Contaminants. Final report. Forest and Rangeland Ecosystem Science Center. National Biological Services. Corvallis, USA

Jacobson JL \& Jacobson SW 1997 Evidence for PCBs as neurodevelopmental toxicants in humans. NeuroToxicology 18 415-424.

Jansen HT, Cooke PS, Porcelli J, Liu TC \& Hansen LG 1993 Estrogenic and antiestrogenic actions of PCBs in the female rat: in vitro and in vivo studies. Reproductive Toxicology 7 237-248.

Januskauskas A, Johannisson A \& Rodriguez-Martinez H 2003 Subtle membrane changes in cryopreserved bull semen in relation with sperm viability, chromatin structure, and field fertility. Theriogenology $60743-758$.

Kavlock RJ 1999 Overview of endocrine disruptor research activity in the United States. Chemosphere 39 1227-1236.

Kim IS, Siril Ariyaratne HB \& Chamindrani Mendis-Handagama SML 2001 Effects of continuous and intermittent exposure of lactating mothers to Aroclor 1242 on testicular steroidogenic function in the adult male offspring. Tissue and Cell 33 169-177.

Korach KS, Emmen JMA, Walker VR, Hewitt SC, Yates M \& Hall JM et al. 2003 Update on animal models developed for analyses of estrogen receptor biological activity. Journal of Steroid Biochemistry and Molecular Biology 86 387-391.

Kunisue T, Someya M, Kayama F, Jin Y \& Tanabe S 2004 Persistent organochlorines in human breast milk collected from primiparae in Dalian and Shenyang, China. Environmental Pollution 131 381-392.

Littell RC, Milliken GA, Stroup WW \& Wolfinger RD 1996 SAS System for Mixed Models. SAS Institute, Cary, NC, USA

Lyche JL, Oskam IC, Skaare JU, Reksen O, Sweeney T \& Dahl E. et al. 2004a Effects of gestational and lactational exposure to low doses of PCBs 126 and 153 on anterior pituitary and gonadal hormones and on puberty in female goats. Reproductive Toxicology 19 87-95.

Lyche JL, Skaare JU, Larsen HJ \& Ropstad E $2004 b$ Levels of PCB 126 and PCB 153 in plasma and tissues in goats exposed during gestation and lactation. Chemosphere 55 621-629.

Mably TA, Moore RW, Bjerke DL \& Peterson RE 1991 In Banbury Report 31: Biological Basis for Risk Assessment of Dioxins and Related Compounds, 31, New York: Cold Spring Harbor Press.

Meerts IATM, Assink Y, Cenijn PH, van den Berg JHJ, Weijers BM \& Bergman A et al. 2002 Placental transfer of a hydroxylated polychlorinated biphenyl and effects on fetal and maternal thyroid hormone homeostasis in the rat. Toxicological Sciences $\mathbf{6 8}$ $361-371$.

Muir D, Braune B, DeMarch B, Norstrom R, Wagemann R \& Lockhart L et al. 1999 Spatial and temporal trends and effects of contaminants in the Canadian Arctic marine ecosystem: a review. The Science of the Total Environment 230 83-144.

Oskam IC, Ropstad E, Dahl E, Lie E, Derocher AE \& Wiig O et al. 2003 Organochlorines affect the major androgenic hormone, testosterone, in male polar bears (Ursus maritimus) at Svalbard. Journal of Toxicology and Environmental Health A $\mathbf{6 6}$ 2119-2139.

Paulenz H, Soderquist L, Adnoy T, Nordstoga A, Gulbrandsen B \& Berg KA 2004 Fertility results after different thawing procedures for ram semen frozen in minitubes and mini straws. Theriogenology 61 1719-1727.

Porterfield SP \& Hendry LB 1998 Impact of PCBs on thyroid hormone directed brain development. Toxicology and Industrial Health 14 103-120.

Rhind SM, Rae MT \& Brooks AN 2001 Effects of nutrition and environmental factors on the fetal programming of the reproductive axis. Reproduction 122 205-214.

Safe SH 1994 Polychlorinated biphenyls (PCBs); environmental impact, biochemical and toxic responses, and implications for risk assessment. Critical Reviews in Toxicology 24 87-149.

Safe SH 2001 Molecular biology of the Ah receptor and its role in carcinogenesis. Toxicology Letters 120 1-7. 
SAS Institute Inc 2003 JMP 5.1, SAS Institute, Cary, NC, USA

Sharpe RM \& Skakkebaek NE 2003 Male reproductive disorders and the role of endocrine disruption: Advances in understanding and identification of areas for future research. Pure and Applied Chemistry 75 2023-2038.

Sharpe RM \& Irvine DS 2004 How strong is the evidence of a link between environmental chemicals and adverse effects on human reproductive health? British Medical Journal 328 447-451.

Skaare JU 2002 Ecological risk assessment of persistent organic chemicals in the Arctic. Toxicology 181 193-197.

Stoker TE, Parks LG, Gray LE \& Cooper RL 2000 Endocrine-disrupting chemicals: prepubertal exposures and effects on sexual maturation and thyroid function in the male rat. A focus on the EDSTAC recommendations. Endocrine Disrupter Screening and Testing Advisory Committee. Critical Reviews in Toxicology 30 197-252.

Suter L, Koch E, Bechter R \& Bobadilla M 1997 Three-parameter flow cytometric analysis of rat spermatogenesis. Cytometry 27 161-168.

Sweeney T, Nicol L, Roche JF \& Brooks AN 2000 Maternal exposure to octylphenol suppresses ovine fetal follicle-stimulating hormone secretion, testis size, and sertoli cell number. Endocrinology 141 $2667-2673$.

Toppari J 2003 Physiology and disorders of testicular descent. Endocrine Development 5 104-109.

Toppari J, Larsen JC, Christiansen P, Giwercman A, Grandjean P \& Guillette LJ et al. 1996 Male reproductive health and environmen- tal xenoestrogens. Environmental Health Perspectives 104 $741-803$.

van den Berg M, Birnbaum L, Bosveld ATC, Brunstrom B, Cook P \& Feeley M et al. 1998 Toxic equivalency factors (TEFs) for PCBs, PCDDs, PCDFs for humans and wildlife. Environmental Health Perspectives 106 775-792.

Vos JG, Dybing E, Greim HA, Ladefoged O, Lambre C \& Tarazona JV et al. 2000 Health effects of endocrine-disrupting chemicals on wildlife, with special reference to the European situation. Critical Reviews in Toxicology 30 71-133.

Waterhouse KE, Haugan T, Kommisrud E, Tverdal A, Olsen G, Farstad W \& De Angelis PM 2005 Relationship between sperm quality measured as plasma membrane-and acrosome-integrity, mitochondrial functionality and DNA-integrity and field fertility of young Norwegian Red bulls. Theriogenology [in press].

Wojtowicz AK, Gregoraszczuk EL, Lyche JL \& Ropstad E 2000 Time dependent and cell-specific action of polychlorinated biphenyls (PCB 153 and PCB 126) on steroid secretion by porcine theca and granulosa cells in mono- and co-culture. Journal of Physiology and Pharmacology 51 555-568.

Received 14 February 2005

First decision 22 April 2005

Revised manuscript received 8 July 2005

Accepted 18 August 2005 